\title{
Modeling Habitat of Freshwater Mussels (Bivalvia:Unionidae) in the Lower Great Lakes 25 Years after the Dreissena Invasion
}

Jonathan M. Bossenbroek

University of Toledo, Jonathan.Bossenbroek@utoledo.edu

Lyubov E. Burlakova

State University of New York at Buffalo

Todd C. Crail

University of Toledo

Alexander Y. Karatayev

State University of New York at Buffalo

Robert A. Krebs

Cleveland State University, r.krebs@csuohio.edu

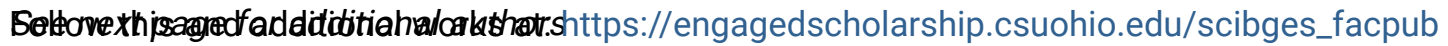

Part of the Biology Commons

How does access to this work benefit you? Let us know!

\section{Recommended Citation}

Bossenbroek, Jonathan M.; Burlakova, Lyubov E.; Crail, Todd C.; Karatayev, Alexander Y.; Krebs, Robert A.; and Zanatta, David T., "Modeling Habitat of Freshwater Mussels (Bivalvia:Unionidae) in the Lower Great Lakes 25 Years after the Dreissena Invasion" (2018). Biological, Geological, and Environmental Faculty Publications. 88.

https://engagedscholarship.csuohio.edu/scibges_facpub/88

This Article is brought to you for free and open access by the Biological, Geological, and Environmental Sciences Department at EngagedScholarship@CSU. It has been accepted for inclusion in Biological, Geological, and Environmental Faculty Publications by an authorized administrator of EngagedScholarship@CSU. For more information, please contact library.es@csuohio.edu. 


\section{Authors}

Jonathan M. Bossenbroek, Lyubov E. Burlakova, Todd C. Crail, Alexander Y. Karatayev, Robert A. Krebs, and David T. Zanatta 


\title{
Modeling habitat of freshwater mussels (Bivalvia:Unionidae) in the lower Great Lakes 25 years after the Dreissena invasion
}

\author{
Jonathan M. Bossenbroek ${ }^{1,5}$, Lyubov E. Burlakova ${ }^{2,6}$, Todd C. Crail ${ }^{1,7}$, Alexander Y. Karatayev ${ }^{2,8}$, \\ Robert A. Krebs ${ }^{3,9}$, and David T. Zanatta ${ }^{4,10}$ \\ ${ }^{1}$ University of Toledo, Department of Environmental Sciences, Lake Erie Center, 6200 Bayshore Road, Oregon, Ohio 43616 USA \\ ${ }^{2}$ Great Lakes Center, State University of New York Buffalo State, 1300 Elmwood Avenue, Buffalo, New York 14222 USA \\ ${ }^{3}$ Department of Biological, Geological, and Environmental Sciences, Cleveland State University, 2121 Euclid Avenue, Cleveland, \\ Ohio 44115 USA \\ ${ }^{4}$ Biology Department, Institute for Great Lakes Research, Central Michigan University, Mount Pleasant, Michigan 48859 USA
}

\begin{abstract}
Finding remnant populations of species that are of conservation concern can be difficult, particularly in aquatic habitats. Models of ecological niches can aid in the discovery of refuges. Remnant populations of native freshwater mussels (unionids) have been found in Lakes Erie and St Clair. Our goals were to predict undiscovered refuges in Lake Ontario based on habitat analysis from Lake Erie and to conduct surveys to test those predictions. We built a presence-only model on environmental data including attributes of the benthic zone and shoreline where mussels occurred in Lake Erie. We found a link between small- and large-scale variables related to unionid persistence. Bathymetry, fetch, and shoreline geomorphology contributed most to the model. These variables correspond to local-scale environmental factors important for unionid survival, including presence of vegetation and substrate composition, which explained $\sim 22 \%$ of the variance in presence, abundance, and richness. The model predicted that $0.8 \%$ of the near-shore area of Lake Ontario should be habitat for unionids. In surveys at 34 locations on the USA shore of Lake Ontario, we found 1800 unionids of 11 species and showed that areas $<500 \mathrm{~m}$ from predicted good habitat contained significantly more individuals than near-shore areas not identified as good habitat. We were able to predict new refuges in Lake Ontario successfully even though mussel assemblages differed between Lakes Erie and Ontario, a result signifying generality of our model for conservation approaches to freshwater mussels.
\end{abstract}

Key words: lake, distribution, MaxEnt, modeling, invertebrates, alien species

Ecological niche or habitat models are being used increasingly to aid in the conservation of rare species because they apply computer algorithms to predict the distribution of a species or assemblage in geographic space (Guisan et al. 2013). Unionid mussels are among the most-imperiled faunal groups in North America (Lydeard et al. 2004). Anthropogenic modification of aquatic systems profoundly reduces potential habitat of mussels and their host fish required for reproduction (Schwalb et al. 2013) through the combination of channel modification and cultural eutrophication (Strayer
2008). The invasion of dreissenid mussels in the Laurentian Great Lakes increased the strain on unionid mussel assemblages because the invader fouled and smothered all historically monitored mussel beds in Lakes Erie (Strayer and Malcom 2007, McGoldrick et al. 2009, Lucy et al. 2014) and Ontario (Burlakova et al. 2014). Despite the environmental changes in the lower Great Lakes, refuges persist (Zanatta et al. 2002, McGoldrick et al. 2009, Crail et al. 2011), and their locations can be used to describe an ecological space where unionid mussels could survive in other

E-mail addresses: ${ }^{5}$ jonathan.bossenbroek@utoledo.edu; ${ }^{6}$ burlakle@buffalostate.edu; ${ }^{7}$ todd.crail@utoledo.edu; ${ }^{8}$ karataay@buffalostate.edu; ${ }^{9}$ r.krebs@ csuohio.edu; ${ }^{10}$ zanat1d@cmich.edu

DOI: 10.1086/697738. Received 16 June 2017; Accepted 21 January 2018; Published online 10 April 2018.

Freshwater Science. 2018. 37(2):330-342. ๑ 2018 by The Society for Freshwater Science. This work is licensed under a Creative Commons AttributionNonCommercial 4.0 International License (CC BY-NC 4.0), which permits non-commercial reuse of the work with attribution. For commercial use, contact journalpermissions@press.uchicago.edu. 
Great Lakes (Zanatta et al. 2015). Unionid refuges have been found in large drowned river mouths, shallow embayments, and coastal wetlands with soft substrates (Zanatta et al. 2015).

The important habitat variables associated with refuges probably are those that inhibit dreissenid establishment (e.g., water-level fluctuations, access by zebra mussel predators) or enable unionids to remove attached dreissenids (Lucy et al. 2014). Unionids can remove attached zebra mussels or reduce zebra mussel settlement in substrates soft enough to permit them to burrow (Nichols and Wilcox 1997, Schloesser et al. 1997, Burlakova et al. 2000, Sherman et al. 2013). Such substrates occur more often in large areas of shallow waters (protected bayous) with low flow and warmer temperatures than elsewhere (Nichols and Wilcox 1997). Additional factors that inhibit establishment of stable zebra mussel populations include wave action, water-level fluctuations, ice scour (Nichols and Wilcox 1997, Karatayev et al. 1998, Bowers and de Szalay 2004, 2005, Sherman et al. 2013), remoteness from a source of dreissenid veligers (Zanatta et al. 2002, McGoldrick et al. 2009), dense reed beds that lower the rate of veliger dispersal (Bodamer and Bossenbroek 2008, Nelson et al. 2009), predation on Dreissena attached to unionids (Bowers and de Szalay 2007), warm thermal plumes from power plants that limit Dreissena presence (Bryan et al. 2013, 2014), and lower $\mathrm{Ca}^{2+}$ concentration in the water (Hollandsworth and Lowe 2011). Many of the specific ecological factors that create refuges apply at limited spatial scales, and most are related to small-scale variables like depth and substrate type. However, large-scale variables (e.g., hydrological regime) may determine sediment type and stability, thereby creating habitat where unionids persist. Incorporation of data on multiple habitat characteristics at known unionid refuges into models can lead to identification of landscapescale predictors that define conditions favorable for taxon persistence (Guisan and Thuiller 2005, Elith et al. 2006, Elith and Graham 2009).

Our primary goal was to predict the habitat in which unionid refuges in Lake Ontario should occur because this large lake had been minimally studied. Our specific objectives were to: 1) use regional-scale geographical information system (GIS) data related to the environmental characteristics at sites in Lake Erie with unionid populations (Crail et al. 2011, Zanatta et al. 2015) to develop a MaxEnt (version 3.3.3k; Phillips et al. 2006) model to predict the presence of unionids at sites in other large lakes infested with dreissenid mussels, and 2) verify model predictions by extensively sampling assemblages in Lake Ontario. We then compared the local-scale characteristics at new sites to those at refuge sites in Lakes Erie and St Clair (Zanatta et al. 2015) to understand how links among small- and large-scale variables may define a refuge for an imperiled freshwater mussel assemblage.

\section{METHODS}

\section{Habitat model}

We selected 35 sites in Lake Erie that had been listed as supporting unionids by Zanatta et al. (2015) (Fig. 1) based on the extent of GIS environmental data available. The environmental variables (Table 1 ) we used for the habitat model were a subset of a suite of variables developed to assess the near-shore habitats of fish and included: 1) physical attributes of the benthic zone (i.e., lake bathymetry, bottom slope, and aspect) and 2) information about the lake shoreline, such as distances to different types of wetlands, sinuosity, fetch, and landuse category (McKenna and Castiglione 2010). Fetch is the distance traveled by wind

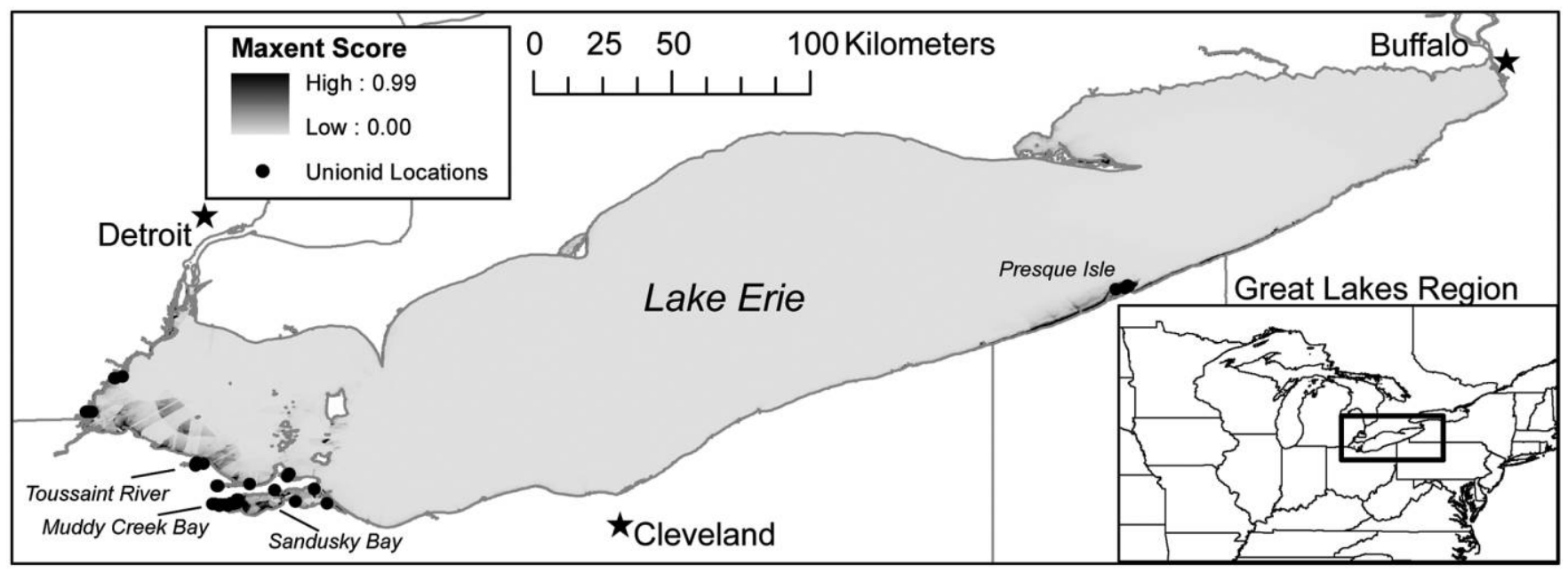

Figure 1. Unionid sites used in MaxEnt modeling. The 35 sites are those sampled by Zanatta et al. (2015) that have unionid assemblages present and are within the extent of the geographic information system layers developed by McKenna and Castiglione (2010). The shading of the map represents the MaxEnt habitat predictions for Lake Erie. 
Table 1. Environmental layers used in the MaxEnt analysis, including a brief description and the importance of each layer for explaining presence of unionids. Shoreline categories include: High $(>15 \mathrm{~m})$ Bluff, High ( $>15 \mathrm{~m})$ Bluff with Beach, Low $(<15 \mathrm{~m})$ Bluff, Low $(<15 \mathrm{~m})$ Bluff with Beach, Sandy/Silty Banks, Clay Banks, Sandy Beach/Dunes, Coarse Beaches, Baymouth Barrier Beaches, Bedrock (Resistant), Bedrock (Non resistant), Low Riverine/Coastal Plain, Open Shoreline Wetlands, Semi Protected Wetlands, Composite, US Shore: Unclassified, Canadian Shore: Artificial, US Shore: Artificial, Canadian Shore: Unclassified.

\begin{tabular}{llr}
\hline \multicolumn{1}{c}{ Environmental layer } & \multicolumn{1}{c}{ Description } & Importance \\
\hline Aspect & Compass direction of slope & 0.5 \\
Bathymetry & Depth $(\mathrm{m})$ & 58.5 \\
Distance to delta-type wetland & Distance $(\mathrm{m})$ to wetlands formed at river mouths & 2.1 \\
Distance to open-type wetland & Distance $(\mathrm{m})$ to wetlands that are open to fluctuations in Great Lakes water levels & 0.2 \\
Distance to protected-type wetland & Distance $(\mathrm{m})$ to wetlands that are protected and controlled by levees, etc. & 5.1 \\
Fetch & Distance along open water over which the wind blows & 15.9 \\
Shoreline geomorphology & Shoreline categories projected outward from coastline & 15.1 \\
Sinuosity & Sinuosity of coastline (ratio of straight line distance to coastline distance) & 1.9 \\
Slope & Submerged bottom slope & 0.6 \\
Submerged aquatic vegetation (SAV) & Binary variable - SAV present on $\geq 50 \%$ of the raster cell area & 0 \\
\hline
\end{tabular}

across open water and, thus, affects wave energy and substrate distribution. The shoreline category data were developed by personnel at the Great Lakes Environmental Research Laboratory of the National Oceanic and Atmospheric Administration to aid in shoreline management (Lee et al. 1998). The extent of the environmental data included the near-shore open water of each Great Lake, i.e., the portion of each lake that is $<10 \mathrm{~m}$ deep. The resolution of the environmental data was $\sim 110 \mathrm{~m}^{2}$ (data were distributed in a geographic coordinate system with cell resolution of $\sim 0.001$ decimal degrees).

Several statistical methods to model ecological niches exist: multivariate analysis (canonical coordinate analysis [CCA] or nonmetric multidimensional scaling [NMDS]), regression-based techniques, and stand-alone modeling systems, such as GARP and MaxEnt (Herborg et al. 2009). To predict potential unionid habitat in Lake Ontario, we used MaxEnt (Phillips et al. 2006), a machine learning method that has been rated highly among similar modeling algorithms (Elith et al. 2006). MaxEnt often enables broader sampling of distributions than other algorithms because presence-only records with background environmental data are sufficient to predict the probability of a species distribution (Doko et al. 2011, Blank and Blaustein 2012, Couce et al. 2012, Matawa et al. 2012). MaxEnt combines: 1) known locations for the organism of interest, and 2) environmental data in the format of a grid of equally sized cells, such that predicted locations fall within the extent of the environmental data. The locations at which a species is present are assumed to provide information on required layers that represent the range of environmental characteristics. MaxEnt identifies the geographical ranges possessing these characteristics (Lozier and Mills 2011). We applied the default settings recommended by Phillips and Dudik (2008) for situations with small sample sizes. We selected 10,000 random pixels from the environmental layers to represent the range of environmental background conditions, a recommended approach when the environmental layers are large. We used all available presence data from Lake Erie to train the model.

The output for MaxEnt models ranges from 0 to 1, with a higher number indicating a better fit to the modeled ecological niche or habitat of an organism of interest. An importance rating for each environmental variable in the model (Table 1) was calculated based on a jack-knife test (Doko et al. 2011), and the overall model was evaluated with the Area Under the Curve (AUC) of the Receiver Operator Characteristics (ROC). The AUC is the probability that the model will correctly differentiate between a presence location and a random location (Phillips et al. 2006, Razgour et al. 2011). Opinions of model assessment vary, but an AUC value $>0.9$ indicates that the model has a high ability to discriminate among locations (Swets 1988, Elith et al. 2006, Phillips et al. 2006).

\section{Lake Ontario surveys}

We used predictions from the niche model to guide our choice of locations to sample for new unionid communities in Lake Ontario. We chose 34 locations in the USA on the southern shore of Lake Ontario that included diverse habitats to test niche model predictions. Within these locations, we selected a total of 54 0.5-ha $(50 \times 100 \mathrm{~m})$ sampling sites based on logistical access and spatial coverage (Fig. 2A). Sampling locations stretched from the lower Niagara River to the Thousand Islands archipelago of the St Lawrence River and included areas in the coastal zone of the lake, mouths of tributary rivers, fringing wetlands (extending from the shore into the littoral zone), wetlands near tributary river mouths, and smaller lakes, ponds, and marshes within the coastal zone near the lake. We assigned multiple sites where the predicted area for mussel habitat 


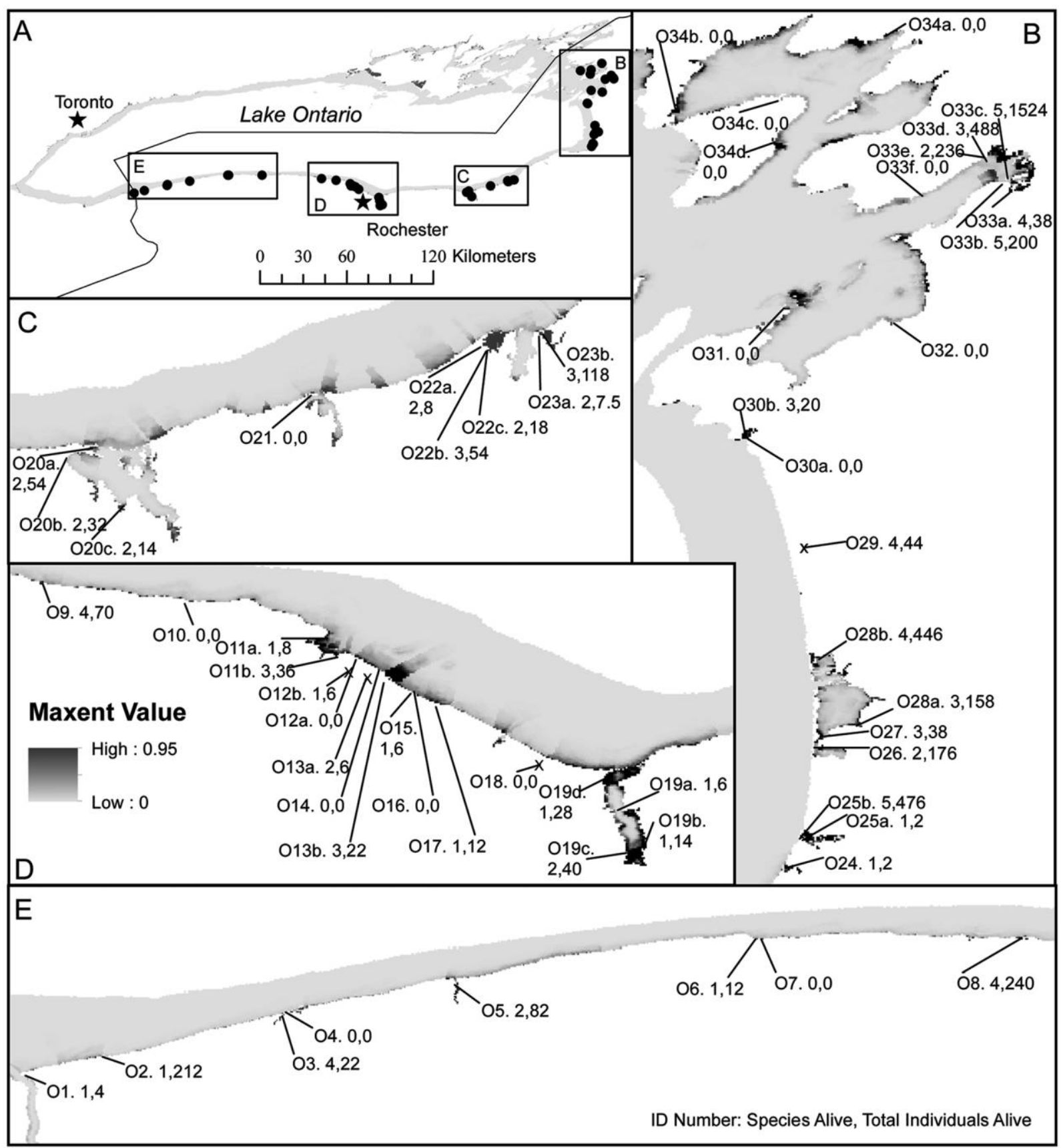

Figure 2. Habitat model predictions of good habitat for unionid assemblages in Lake Ontario based on known occurrences in Lake Erie. A.-Overview of the sampling sites in Lake Ontario used to assess the niche model results. The 4 boxes in panel A are expanded in B-E to show niche model results in gray-scale and the number of species and individuals found alive at each sampling location (identification numbers of sampling locations correspond to Table 2).

was large or heterogeneous in habitat. Where predicted mussel abundances were high, we sampled 1 to 5 sites and included additional sampling sites outside target areas (Fig. 2B-E).

We did not expect to find a tight correlation between model predictions and unionid species number or abundance because unionid assemblages have patchy spatial distributions, and the grain size (i.e., scale) of our environ- mental data probably was of a lower resolution than that needed to predict variations in sediment stability precisely. Therefore, we calculated correlations between model predictions and survey results first and then used ArcGIS (version 10.1; Environmental Systems Research Institute, Redlands, California) to compare sampling locations inside or close to areas of good habitat (see definition below). We arbitrarily defined 'close' as the area $<500 \mathrm{~m}$ from predicted 
good habitat. Therefore, some shallow-water locations with low predicted values also were chosen to assess the model. Four locations selected were not within the extent of our habitat predictions (sites O12b, O13a, O18, and O29; Fig. 2B, D), but these types of connected wetlands are frequent refuges for unionids in the Lake Erie basin (Bowers and de Szalay 2004, 2005). Therefore, we sampled them to meet the secondary project objective, which was to find as many unionid refuges as possible with limited time and resources.

We searched each site for unionids for 2 person-hours (e.g., 4 searchers for $30 \mathrm{~min}$ ) using tactile searches while wading and snorkeling. These searches followed the methods used by Zanatta et al. (2015) for Lakes Erie and St Clair. We calculated the mean ( \pm SE, unless noted otherwise) number of unionids/site by averaging data from multiple sites sampled in each location. Species richness was the cumulative number of unionid species present across sites within a location. We calculated unionid diversity based on the Shannon diversity index $\left(\mathrm{H}^{\prime}\right)$ and converted $\mathrm{H}^{\prime}$ to effective number of species, which is the number of species in an assemblage if all species present were equally abundant $\left(e^{\mathrm{H}^{\prime}}\right.$; Jost 2006). At 4 sites where we found abundant or diverse mussel assemblages, we conducted quantitative area searches (30-60 randomly placed $0.25-\mathrm{m}^{2}$ quadrats) for better assessments of density.

\section{Local-scale variation}

We measured local-scale habitat characteristics following the procedure used by Zanatta et al. (appendices 1, 2 by Zanatta et al. 2015). We collected measurements from each site in triplicate, typically at the center and 2 opposite corners of the site. We estimated proportional composition of sediments (bedrock, boulder, cobble, gravel, sand, silt, and clay) qualitatively to a maximum depth of $12 \mathrm{~cm}$. We used a multiparameter water-quality sonde (model 6600 V2; Yellow Springs International, Yellow Springs, Ohio) to measure turbidity, specific conductivity, $\mathrm{pH}$, chlorophyll $a(\mathrm{Chl} a)$, and temperature. At each site, we estimated density of dreissenids qualitatively as absent (none found), low (few aggregations), medium (many aggregations), or high (all hard substrates covered); \% emergent and submerged macrophyte cover; and habitat threats, such as visible sediment disturbance, pollution, and nearby watershed development.

We assessed quantitative relationships among local-scale environmental variables for 3 aspects of community composition, total abundance, species richness, and presence/ absence of unionids based on combined data across Lakes Erie/St Clair and Ontario (Appendix S1). For a few sites where complete environmental data were not collected during surveys, we estimated missing data with the aid of the Multivariate Imputation by Chained Equations package for $\mathrm{R}$ (version 3.2.3; R Project for Statistical Computing, Vienna,
Austria; van Buuren and Groothuis-Oudshoorn 2011). To find a best-fit model and estimate model coefficients we used the $\mathrm{R}$ package glmulti, which automates model selection with generalized linear models (GLMs) based on a genetic algorithm and uses Akaike's Information Criterion (AIC) to assess model fit (Calcagno 2013). For each model selection routine we used glmulti to identify those models $<2$ AIC units from the best-fit model, calculate model-averaged coefficient estimates and significance values of each variable, and estimate the $r^{2}$ value of the best-fit model.

\section{RESULTS}

The model selected by MaxEnt for the habitat of unionids in Lake Erie included 10 predictor variables ( $\mathrm{Ta}$ ble 1) and had an AUC of 0.988. Shoreline geomorphology, bathymetry or depth, and fetch contributed the most to this model, as determined by the jackknife routine (Fig. 3A-C). The most important shoreline category was semi-protected wetlands, which were areas defined as having protection from wave action via natural features, such as Baymouth barriers (EC and USEPA 2009).

The distribution of MaxEnt values at the 35 Lake Erie/ St Clair sites used to develop the model was bimodal, and all but 9 sites had values $>0.4$. Therefore, we defined 0.4 as a threshold value to indicate good mussel habitat. The 9 sites with a MaxEnt value $<0.4$ were $<500 \mathrm{~m}$ from an area defined as good habitat. For Lake Erie, the model predicted that only $65.5 \mathrm{~km}^{2}(0.2 \%)$ of near-shore area is good habitat for mussels. For Lake Ontario, the model predicted that $55 \mathrm{~km}^{2}(0.8 \%)$ of the near-shore habitat is good for unionids. Thus, the total area of predicted good habitat was similar between lakes, but the proportion of good habitat was greater in smaller Lake Ontario. For the Lake Erie localities from which the model was developed, model predictions (i.e., likelihood of occurrence or suitable habitat) were positively related to the number of species found (adj. $R^{2}=0.09, p=$ $0.007)$ and the number of individuals within a survey site $\left(\right.$ adj. $\left.R^{2}=0.08, p=0.009\right)$. In Lake Ontario, the relationships between model predictions and number of species and number of individuals were not significant. However, the number of individuals at sites $<500 \mathrm{~m}$ from areas the model predicted to be good (Fig. 2B-E) was greater (44.7 \pm 13.9$)$ than in areas farther from predicted good habitat (11.2 \pm 3.9; Student's $t$-test, $p<0.01$; Table 2).

We collected 1800 unionids representing 11 species across the 54 sites at 34 different locations in Lake Ontario (Table 3). These sites included open and cutoff bays, mouths of tributaries, and nearby wetlands, where the most dispersed and abundant species were Pyganodon grandis (65\% of sampled locations), Elliptio complanata (47\% of locations), and Lampsilis radiata (38\% of locations) (Table 3). We combined specimens of $P$. grandis and P. cataracta and specimens of L. radiata and Lampsilis siliquoidea in species counts because of taxonomic ambiguity and poten- 

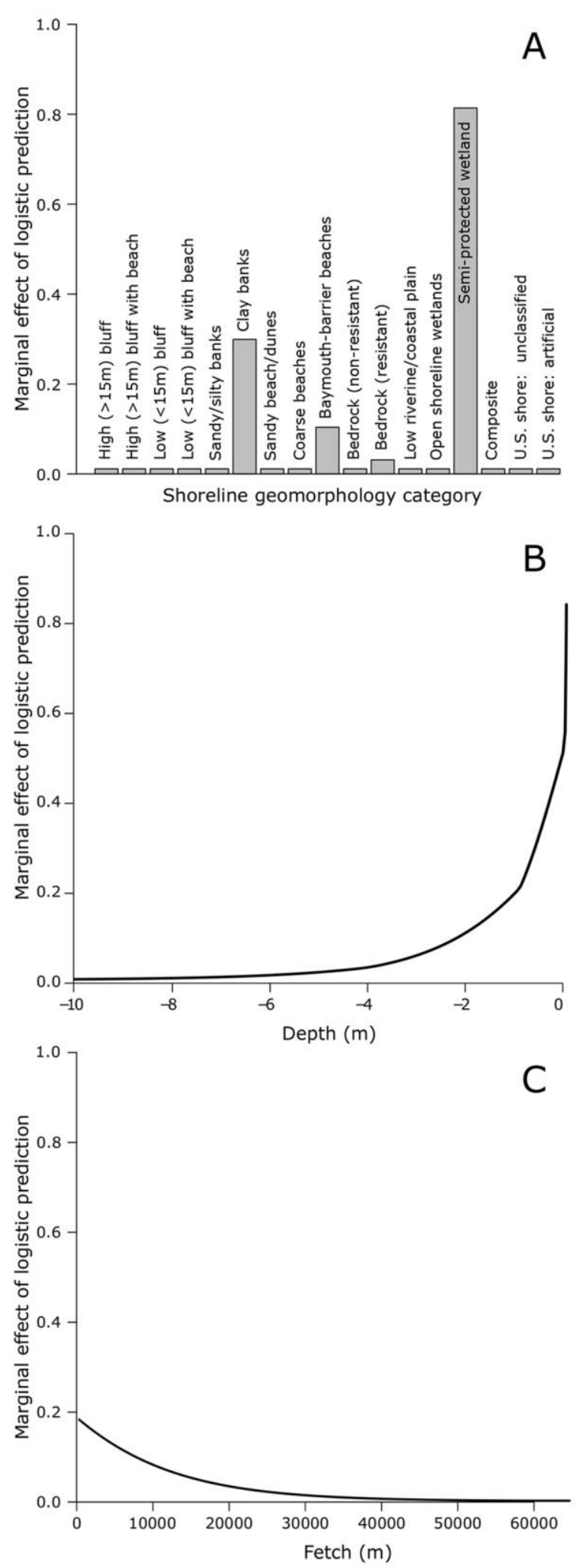

Figure 3. Marginal effect of shoreline geomorphology (A), depth (B), and fetch $(\mathrm{C})$, the 3 predictor variables in the final MaxEnt model on the prediction of suitable habitat for unionid mussels in Lake Erie. tial for hybridization in the Lake Ontario drainage (e.g., Kat 1986), but we did confirm their presence. The other 6 species were less abundant and were observed at only 2 to $9 \%$ of sites. The most species-rich refuges were in the eastern part of the lake. We identified 7 species in Black River Bay (site O33), and we found 239 live individuals belonging to 5 species during timed searches and an additional 71 mussels in quadrat searches in the mouth of Salmon River (site O25) where density was estimated at $4.7 \mathrm{ind} / \mathrm{m}^{2}$.

More than 3700 individuals of 25 unionid species were documented in combined surveys of Lakes Ontario, St Clair, and Erie and the Detroit River (Appendix S1). Sites with live unionids had a significantly higher coverage of emergent (Mann-Whitney $U$ test, $p=0.017$ ) and submerged vegetation $(p=0.002)$, a larger proportion of silt substrates $(p=0.009)$, and deeper soft substrates $(p<0.0001)$ than other sites. Our best-fit model for the total number of live individuals (Table 4) included temperature, and \% bedrock, boulder, clay, cobble, mud, and sand as important variables $\left(R^{2}=0.15, p<0.01\right)$. Location (either in Lakes St Clair/Erie or Ontario), submerged vegetation, temperature, and \% mud best explained species richness $\left(R^{2}=0.12, p<0.01\right)$. The variables that explained $25 \%$ of the variance in the presence or absence of unionids at any particular site included \% submerged and emergent macrophytes, dreissenid density, mean temperature, $\mathrm{pH}$, and \% gravel and mud $\left(R^{2}=0.25, p<0.01\right)$ (Table 4).

\section{DISCUSSION}

The MaxEnt model based on Lake Erie habitat successfully predicted the locations of extant mussel assemblages in Lake Ontario even though $<1 \%$ of the near-shore areas of both lakes were predicted as good habitat. Our predictions were successful even though assemblages of Lakes Erie and Ontario were very different in the species present. Species richness in Lake Ontario $(n=11)$ currently is only $1 / 2$ of that of refuges in Lakes Erie and St Clair (Zanatta et al. 2015), but all of these lakes once supported many more species than at present (Strayer and Jirka 1997, Graf 2002). The results, given so much change through time, suggest transferability of the model across species in the Unionidae (Wenger and Olden 2012). In support, models developed for individual species yielded predictions similar to those of our model based on assemblage composition (and therefore were not shown), and together they show how largescale variables can be used in management to define lake habitat for unionid mussels broadly, whether in dreissenidinfested or dreissenid-free lakes. The ecological character of shore-zone ecosystems is set by the inputs of physical energy, the hydrologic regime, inputs of nutrients, the biota, geologic (or anthropogenic) structure of the shore and its environs, and the climate (reviewed in Strayer and Findlay 2010). Small-scale variables, such as sediment composition 
Table 2. Names and codes for 34 locations in coastal areas of Lake Ontario with the number of 0.5-ha sites sampled at a location, mean ( \pm SE for locations with multiple sites) number of unionids collected/site, species richness of each location (site[s]), and those sites $<500 \mathrm{~m}$ from good habitat.

\begin{tabular}{|c|c|c|c|c|c|c|c|}
\hline Location code & Location & County & No. sites & Unionids/site & SE & Richness & $\begin{array}{c}\text { Sites }<500 \mathrm{~m} \text { from a location } \\
\text { with model value } \geq 0.4\end{array}$ \\
\hline $\mathrm{O} 1$ & Niagara River & Niagara & 1 & 4 & & 1 & 0 \\
\hline $\mathrm{O} 2$ & Four Mile Creek & Niagara & 1 & 212 & & 1 & 0 \\
\hline $\mathrm{O} 3$ & Twelve Mile Creek & Niagara & 1 & 22 & & 4 & 0 \\
\hline $\mathrm{O} 4$ & Roosevelt Beach & Niagara & 1 & 0 & & 0 & 0 \\
\hline O5 & Eighteen Mile Creek & Niagara & 1 & 82 & & 2 & 1 \\
\hline O6 & Golden Hill Creek & Niagara & 1 & 12 & & 1 & 0 \\
\hline O7 & Golden Hill State Park & Niagara & 1 & 0 & & 0 & 0 \\
\hline O8 & Johnson's Creek & Niagara & 1 & 240 & & 4 & 0 \\
\hline O9 & Sandy Creek & Monroe & 1 & 70 & & 4 & 0 \\
\hline $\mathrm{O} 10$ & Bush Creek & Monroe & 1 & 0 & & 0 & 0 \\
\hline $\mathrm{O} 11$ & Braddock Bay & Monroe & 2 & 22 & 14 & $3(3,1)$ & 1,1 \\
\hline $\mathrm{O} 12$ & Cranberry Pond & Monroe & 2 & 3 & 3 & $1(0,1)$ & 1,1 \\
\hline $\mathrm{O} 13$ & Long Pond & Niagara & 2 & 14 & 8 & $3(2,3)$ & 1,1 \\
\hline $\mathrm{O} 14$ & Grandview Beach & Monroe & 1 & 0 & 0 & 0 & 1 \\
\hline $\mathrm{O} 15$ & Buck Pond & Monroe & 1 & 6 & & 1 & 1 \\
\hline $\mathrm{O} 16$ & Crescent Beach & Monroe & 1 & 0 & & 0 & 1 \\
\hline $\mathrm{O} 17$ & Round Pond & Monroe & 1 & 12 & & 1 & 1 \\
\hline $\mathrm{O} 18$ & Eastman-Durhem Park & Monroe & 1 & 0 & & 0 & 1 \\
\hline O19 & Irondequoit Bay & Monroe & 4 & 22 & 7.5 & $2(1,1,2,1)$ & $1,1,1,1$ \\
\hline $\mathrm{O} 20$ & Sodus Bay & Wayne & 3 & 33 & 11.6 & $3(2,2,2)$ & $0,0,0$ \\
\hline $\mathrm{O} 21$ & Port Bay & Wayne & 1 & 0 & & $0(0)$ & 1 \\
\hline $\mathrm{O} 22$ & Blind Sodus Bay & Wayne & 3 & 26.7 & 14.0 & $3(2,3,2)$ & $1,1,1$ \\
\hline $\mathrm{O} 23$ & Fair Haven State Park & Wayne & 2 & 62.8 & 55.2 & $3(2,3)$ & 1,1 \\
\hline $\mathrm{O} 24$ & Selkirk State Park & Oswego & 1 & 2 & & 1 & 0 \\
\hline $\mathrm{O} 25$ & Salmon River & Oswego & 2 & 239 & 237 & $5(1,5)$ & 0,1 \\
\hline $\mathrm{O} 26$ & South Sandy Pond & Oswego & 1 & 176 & & $2(1)$ & 1 \\
\hline $\mathrm{O} 27$ & North Bay & Oswego & 1 & 38 & & $3(1)$ & 1 \\
\hline $\mathrm{O} 28$ & North Pond & Oswego & 2 & 302 & 144 & $4(3,4)$ & 1,1 \\
\hline O29 & Lake View Pond & Jefferson & 1 & 44 & & 4 & 0 \\
\hline $\mathrm{O} 30$ & El Durado Bay & Jefferson & 2 & 10 & 10 & $3(0,3)$ & 1,1 \\
\hline O31 & Association Island & Jefferson & 1 & 0 & & 0 & 0 \\
\hline O32 & Henderson Bay & Jefferson & 1 & 0 & & 0 & 0 \\
\hline $\mathrm{O} 33$ & Black River Bay & Jefferson & 6 & 414.3 & 232.9 & $7(4,5,3,0,5,0)$ & $1,1,1,1,1,0$ \\
\hline O34 & Chaumonte Bay & Jefferson & 4 & 0 & 0 & $0(0,0,0,0)$ & $0,1,1,1$ \\
\hline
\end{tabular}

and depth and vegetation, have been identified previously as indicative of refuges (Lucy et al. 2014). We expanded this list to include larger-scale variables-depth, fetch, and shoreline geomorphology. These variables also are good predictors for fishes (Chu et al. 2014). In general, more mussels were predicted at shallow depths and where fetch was short (Nichols and Wilcox 1997). Bathymetry and shore elevation control the input of physical energy to shoreline habitats. Therefore, they define substrate stability, sedi- ment composition, grain size, nutrient and organic content, redox state, inputs of on- and off-site production of organic matter, intensity of predation, presence and zonation of vegetation, and consequently, unionid distributions (Gangloff and Feminella 2007, Strayer 2008, Strayer and Findlay 2010). Depth was the single-most important predictor of unionid habitat. In western Lake Erie and eastern Lake Ontario, shallow areas can have river-like conditions (Haag 2012), modulated by fetch and shoreline geomor- 




This content downloaded from 137.148.114.252 on May 31, 2018 06:20:24 AM

All use subject to University of Chicago Press Terms and Conditions (http://www.journals.uchicago.edu/t-and-c). 
Table 4. Model-averaged estimated coefficients (Est coef) and relative model importance (MI) for the variables included in regression models of the total number of individuals found live, total species richness, and the presence or absence of unionids by local-scale variable across sampling sites in Lakes Ontario, Erie, and St Clair. Model-averages were based on models with an Akaike's Information Criterion (AIC) value $<2$ AIC units of the best-fit model. Coefficients in bold were contained in the overall best-fit model. The muliple $R^{2}$ value for each best-fit model is in parentheses. ${ }^{*}=p<0.1{ }^{* * *}=<0.05$. Blank indicates not significant.

\begin{tabular}{|c|c|c|c|c|c|c|}
\hline \multirow[b]{2}{*}{ Variables selected } & \multicolumn{2}{|c|}{ Total alive $\left(R^{2}=0.15\right)$} & \multicolumn{2}{|c|}{ Richness $\left(R^{2}=0.12\right)$} & \multicolumn{2}{|c|}{ Presence/Absence $\left(R^{2}=0.25\right.$} \\
\hline & Est Coef & MI & Est Coef & MI & Est Coef & MI \\
\hline Intercept & $-97.63^{* * *}$ & 1.00 & -2.35 & 1.00 & 0.03 & 1.00 \\
\hline Depth maximum & -0.04 & 0.06 & 0.01 & 0.06 & 0.00 & 0.06 \\
\hline Depth minimum & -0.45 & 0.08 & & & -0.01 & 0.10 \\
\hline Dressenid low & & & 0.08 & 0.11 & $0.21^{* * *}$ & 1.00 \\
\hline Dressenid med & & & 0.12 & 0.11 & $0.26^{\text {***; }}$ & 1.00 \\
\hline Dressenid high & & & 0.10 & 0.11 & -0.05 & 1.00 \\
\hline Location & 0.16 & 0.06 & $-0.86^{\text {*** }}$ & 1.00 & 0.00 & 0.04 \\
\hline$\%$ bedrock & $10.28^{* * *}$ & 1.00 & 0.02 & 0.08 & 0.01 & 0.13 \\
\hline$\%$ boulder & $10.70^{* * *}$ & 1.00 & 0.00 & 0.06 & 0.00 & 0.05 \\
\hline$\%$ clay & $3.76^{* * *}$ & 1.00 & 0.00 & 0.06 & 0.00 & 0.06 \\
\hline$\%$ cobble & $4.63^{*}$ & 0.92 & & & 0.00 & 0.06 \\
\hline$\%$ gravel & -0.16 & 0.08 & -0.02 & 0.12 & $-0.05^{* *}$ & 1.00 \\
\hline$\%$ mud & $4.33^{* * *}$ & 1.00 & $0.30^{* * *}$ & 1.00 & $0.04^{*}$ & 0.94 \\
\hline$\%$ organic & -0.40 & 0.09 & & & 0.00 & 0.05 \\
\hline$\%$ sand & $6.30^{* * *}$ & 1.00 & 0.01 & 0.10 & 0.00 & 0.04 \\
\hline Macrophyte emergent & 0.03 & 0.06 & 0.02 & 0.11 & $0.09^{* *}$ & 1.00 \\
\hline Macrophyte submerged & 0.29 & 0.13 & $0.29^{* * *}$ & 1.00 & $0.03 \%$ & 0.82 \\
\hline Mean $\mathrm{pH}$ & 0.47 & 0.08 & -0.02 & 0.08 & $-0.11 *$ & 0.88 \\
\hline Mean temperature & $2.79 * \%$ & 1.00 & $0.12^{* * *}$ & 1.00 & $0.05^{* *}$ & 1.00 \\
\hline Threats & -0.40 & 0.11 & -0.01 & 0.07 & 0.00 & 0.05 \\
\hline
\end{tabular}

phology, that influence sediment supply. Energy extremes can reduce species richness, and a 'Goldilocks zone' may exist between areas where energy is too high and leads to bed scouring and armoring and areas where energy is too low and fine sediment over-accumulates (Dila and Biddanda 2015).

Peak wave heights offshore and peak wave energy impinging on shoreline are directly related to fetch (Denny 1988). Therefore, fetch was one of the most important largerscale variables in our model of unionid refuges. Fetch also strongly influences grain size and stability of shore sediment and the presence of vegetation, all of which affect habitat structure (Gangloff and Feminella 2007, Newton et al. 2008, Zigler et al. 2008, Daraio et al. 2010). The distribution of unionid mussels in small inland lakes is strongly influenced by fetch (Cyr 2009) and, in coastal wetlands in Lake Huron, abundances of insects were higher and abundances of crustaceans and gastropods were lower in regions with longer fetch than in other regions (Cooper et al. 2014). The sinuosity (or curvature) of the shoreline can influence fluvial processes by creating breaks in fetch and, therefore, may structure littoral freshwater mussel assemblages (Harris et al. 2011). For example, in Sandusky Bay of Lake Erie, 2 oppo- site rip-rap-hardened points create a channel through which fetch is unimpeded. Unionid assemblages appear to be restricted to a narrow band along the leeward sides of each point, where heterogeneous substrates accumulate as a response to the interactive effects of depth, fetch, and sinuosity.

Shoreline geomorphology and the distance to different wetland types composed a $2^{\text {nd }}$ set of factors that affected unionid presence. Shoreline geomorphology determines a gradient of shores from reflective (e.g., vertical seawalls that reflect nearly all incident wave energy), to dissipative (e.g., gently sloping beaches that dissipate nearly all incident wave energy). Species richness, abundance and biomass of aquatic macroinvertebrates, and biological interactions increase with the ability of the shore zone to dissipate wave energy, and ecological processes increase from dissipative and ultradissipative shores to tidal flats (Defeo and McLachlan 2005, Strayer and Findlay 2010). By providing protection from strong physical forces, dissipative shallow shores allow establishment of emerged and submerged macrophytes that further absorb wave energy, reduce near-bed shear stress, stabilize shores and flow patterns, and increase local sediment deposition. Unionid abundance and species diversity were 
positively related to coverage of emerged and submerged macrophytes across our studied lakes.

Not all shore geomorphological classification types occur in both Lakes Erie and Ontario, so geomorphic categorizations may have to be modified for applicability to mussels (McKenna and Castiglione 2010, Chu et al. 2014). Nevertheless, these large-scale descriptors still provided predictive power. Unionids were found more often in deep soft substrates and where vegetation coverage was greater, e.g., in the large marshy bay formed by the Black River in eastern Lake Ontario and in the western basin of Lake Erie (Zanatta et al. 2015). These habitats can be described as dissipative or ultradissipative shores with vegetation or in short, semi-protected wetlands. Our model predicted that a combination of shallow dissipative shores with abundant vegetation, i.e., sites categorized as semi-protected wetland, was associated with a higher probability of suitable habitat for unionid mussels. Semi-protected wetlands occur in areas protected by natural barriers, which may reduce dreissenid colonization or create conditions appropriate for ideal sediment composition. Among the lakes in our study, Lake Erie has the highest concentration of coastal marshes (Herdendorf 1992). In this lake, unionids occurred in Muddy Creek Bay, Toussaint Creek, and 5 sites at Presque Isle, all of which are close to semi-protected wetlands. Lake Ontario possesses less shoreline categorized as semi-protected wetland, but the site with the $2^{\text {nd }}$-highest unionid densities was in an area classified as open shoreline wetland. The other 2 sites with high densities (>200 ind/ha) were categorized as sandy beach/ dunes.

Hydrological regime, or the pattern of change in water level over time, strongly influences the composition and activities of the shore-zone biota because it controls many aspects of ecosystem function (Strayer and Findlay 2010) and the shore-zone vegetation (Keddy and Reznicek 1986, Hill et al. 1998). Irregular fluctuations in water level can inhibit establishment of stable populations of dreissenids and can prevent colonization of unionids by dreissenids (Nichols and Wilcox 1997, Karatayev et al. 1998, Bowers and de Szalay 2004, 2005, Sherman et al. 2013). Nevertheless, positive associations between unionid and dreissenid presence are observed (Burlakova et al. 2014), perhaps because where physical forces or other factors extirpate unionids, they also extirpate dreissenids (Nichols and Wilcox 1997, Karatayev et al. 1998, Sherman et al. 2013). We cannot be sure that unionid communities have now equilibrated to the dreissenid invasions, but the number of unionids infested with Dreissena has declined dramatically, especially in lakes dominated by Dreissena $r$. bugensis (Burlakova et al. 2014), and some unionid communities in Lake St Clair and western Lake Erie appear to be stable or increasing in densities (Crail et al. 2011, Zanatta et al. 2015).

In Lake Ontario, large declines in species richness were recorded by the $2^{\text {nd }}$ half of the $20^{\text {th }}$ century. The 17 species documented in the Lake Ontario drainage before the 1960s fell to 11 before the dreissenid invasion (Strayer and Jirka 1997). In this same period, $1 / 3$ of the 33 species present in the St Clair and Lake Erie drainages (Metcalfe-Smith et al. 1998) were lost (Zanatta et al. 2015), although the loss was less severe in shallow Lake St Clair (Zanatta et al. 2015). Moreover, the relative abundance of individual species is changing. In Lake Ontario, E. complanata was found at almost $1 / 2$ of all locations and made up $64 \%$ of all mussels recorded in the survey. Along with its much more common western counterpart, Elliptio dilatata, this species appears to be gone from Lake Erie today (Graf 2002). Lampsilis radiata, also historically more prevalent in Lake Ontario than its western counterpart, L. siliquoidea (Strayer and Jirka 1997), remains abundant and was found at 38\% of Lake Ontario locations, whereas $L$. siliquoidea fell from a relative abundance of $60 \%$ to $<1 \%$ in Lake Erie (Zanatta et al. 2015).

The relative abundance of another species in the nearshore mussel assemblages of Lake Erie, Quadrula quadrula, has increased, and its distribution in Lake Erie may have expanded in the last few decades (Zanatta et al. 2015). We did not find Q. quadrula in our surveys of southern Lake Ontario, but recently it was discovered in abundance in a few coastal embayments and drowned river mouths in western Lake Ontario in Canada (Hoffman et al. 2018). This discovery brings total diversity in the lake to 12 species. A $2^{\text {nd }}$ common species, $P$. grandis, and possible $P$. cataracta hybrids, were present in $16 \%$ of the sites sampled in the lower Great Lakes between 1860 and 1960, 45\% of sites after 1960 (Metcalfe-Smith et al. 1998), 38\% of sites sampled in Lakes Erie and St Clair in 2011-2012 (Zanatta et al. 2015), and $64 \%$ of sites in Lake Ontario in 2012. These results correspond to its increased relative abundance across the lower Great Lakes (Metcalfe-Smith et al. 1998). Leptodea fragilis also may be expanding back into the Great Lakes (Bryan et al. 2013, Krebs et al. 2015) and may begin to increase in Lake Ontario.

We did not include host fish in our model. Host-fish distribution is an important dimension of the fundamental niche for freshwater mussels (Haag and Warren 1998) and could be incorporated in future models of lakeshore habitat. In rivers, watershed size is correlated with species richness of fishes and mussels (Bauer et al. 1991, Watters 1992), but relationships in richness between the 2 groups tends to disappear after accounting for area effects (Rashleigh 2008, Krebs et al. 2010) or habitat variation (Inoue et al. 2017). Instead, fish and unionid assemblages may respond independently to the same habitat variables, suggesting that simple models might be transferable between assemblages (Wenger and Olden 2012).

\section{Conclusion}

Our habitat model identified large- and small-scale habitat variables that appear to define refuges despite differences in taxonomic composition among mussel assemblages 
in these lakes. Depth was the most important predictor and together with fetch and shoreline geomorphology enabled us to predict a high likelihood of finding patches of unionids and small-scale factors like stable substrate (deep, silty sediments) and vegetation. These sites were protected areas with shorter fetch, smaller slope, shallower depth, and higher shoreline sinuosity, which combined as semi-protected wetlands to allow accumulation of organic matter.

Application of this model to Lake Ontario enabled us to discover large assemblages of threatened native unionid species. Dreissenids continue to spread in North America and Europe, and a similar byssate bivalve, Limnoperna fortunei, currently spreading in South America (Boltovskoy and Correa 2015), is predicted to invade freshwaters in the near future. Fine-tuning models on a variety of water bodies across continents will aid in defining habitats that can protect native unionid species prior to or after invasion.

\section{ACKNOWLEDGEMENTS}

Author contributions: JMB conducted the modeling, statistical analyses and led the writing; LEB contributed to Lake Erie sampling, led Ontario sampling, and contributed to writing; TCC contributed to Lake Erie sampling and contributed to writing; AYK contributed to sampling in Lakes Erie and Ontario; RAK contributed to sampling on lakes Erie and Ontario, and substantial contribution to the writing; DTZ was the lead principal investigator on our larger project, supplied data from Lake St Clair, assisted in Lake Erie sampling, and contributed to writing.

Funding for this project was provided by the US Fish and Wildlife Service, Great Lakes Fish and Wildlife Restoration Act (project no. 30191-A-G152). Scientific collection permits were provided by wildlife agencies of Michigan, Ohio, Pennsylvania, New York, and Ontario. We extend special thanks to the dive crew, J. Bateman, G. Longton, D. Okon, and M. Shackelford from DTE Energy. Additional assistance in the field was provided by D. Schloesser from the US Geological Survey, Great Lakes Science Center; W. Paterson, T. Griffith, M. Rowe, M. Scott, E. Nederhoed, J. Bergner, J. Twichell, E. Bertram, L. Adams, L. Kolich, and E. Marlow from Central Michigan University; F. de Szalay, B. Morgan, M. Hickin, B. Brdek, J. Martin, and K. Shreve from Kent State University; B. Tulumello and K. Bauer at SUNY Buffalo State; M. Begley from Cleveland State University; N. Bryan, C. Florence, S. Schnapp, J. Sieracki, and L. Volmar from the University of Toledo; M. Walsh, E. Meyer, R. Miller, A. Halmi, and C. Folb from the Western Pennsylvania Conservancy; E. Masteller from the Tom Ridge Environmental Center; and V. Karatayev and I. Porto-Hannes from SUNY University at Buffalo. This article is contribution 97 of the Central Michigan University Institute for Great Lakes Research and 201801 of the University of Toledo Lake Erie Center.

\section{LITERATURE CITED}

Bauer, G., S. Hochwald, and W. Silkenat. 1991. Spatial distribution of freshwater mussels: the role of host fish and metabolic rate. Freshwater Biology 26:377-386.

Blank, L., and L. Blaustein. 2012. Using ecological niche modeling to predict the distributions of two endangered amphibian species in aquatic breeding sites. Hydrobiologia 693:157-167.
Bodamer, B. L., and J. M. Bossenbroek. 2008. Wetlands as barriers: effects of vegetated waterways on downstream dispersal of zebra mussels. Freshwater Biology 53:2051-2060.

Boltovskoy, D., and N. Correa. 2015. Ecosystem impacts of the invasive bivalve Limnoperna fortunei (Golden Mussel) in South America. Hydrobiologia 746:81-95.

Bowers, R., and F. A. de Szalay. 2004. Effects of hydrology on unionids (Unionidae) and zebra mussels (Dreissenidae) in a Lake Erie coastal wetland. American Midland Naturalist 151:286300.

Bowers, R., and F. A. de Szalay. 2005. Effects of water level fluctuations on zebra mussel distribution in a Lake Erie coastal wetland. Journal of Freshwater Ecology 20:85-92.

Bowers, R., and F. A. de Szalay. 2007. Fish predation of zebra mussels attached to Quadrula quadrula (Bivalvia:Unionidae) and benthic molluscs in a Great Lakes coastal wetland. Wetlands 27:203-208.

Bryan, N. J., C. V. Florence, T. D. Crail, and D. L. Moorhead. 2013. Freshwater mussel community response to warm water discharge in western Lake Erie. Iournal of Great Lakes Research 39:449-454.

Bryan, N. J., D. L. Moorhead, and T. D. Crail. 2014. Habitat characteristics of a unionid refuge in the thermal plume of a power plant in western Lake Erie. Journal of Great Lakes Research 40: 699-704.

Burlakova, L. E., A. Y. Karatayev, and D. K. Padilla. 2000. The impact of Dreissena polymorpha (Pallas) invasion on unionid bivalves. International Review of Hydrobiology 85:529-541.

Burlakova, L. E., B. L. Tulumello, A. Y. Karatayev, R. A. Krebs, D. W. Schloesser, W. L. Paterson, T. A. Griffith, M. W. Scott, T. Crail, and D. T. Zanatta. 2014. Competitive replacement of invasive congeners may relax impact on native species: interactions among zebra, quagga, and native unionid mussels. PLoS ONE 9:e114926.

Calcagno, V. 2013. glmulti: model selection and multimodel inference made easy. $\mathrm{R}$ package, version 1.0.7. $\mathrm{R}$ Project for Statistical Computing, Vienna, Austria. (Available from: https:// CRAN.R-project.org/package $=$ glmulti)

Chu, C., M. A. Koops, R. G. Randall, D. Kraus, and S. E. Doka. 2014. Linking the land and the lake: a fish habitat classification for the nearshore zone of Lake Ontario. Freshwater Science 33:1159-1173.

Cooper, M. J., G. A. Lamberti, and D. G. Uzarski. 2014. Spatial and temporal trends in invertebrate communities of Great Lakes coastal wetlands, with emphasis on Saginaw Bay of Lake Huron. Journal of Great Lakes Research 40:168-182.

Couce, E., A. Ridgwell, and E. J. Hendy. 2012. Environmental controls on the global distribution of shallow-water coral reefs. Lournal of Biogeography 39:1508-1523.

Crail, T. D., R. A. Krebs, and D. T. Zanatta. 2011. Unionid mussels from nearshore zones of Lake Erie. Iournal of Great Lakes Research 37:199-202.

Cyr, H. 2009. Substrate and fetch affect the emergence of freshwater mussels from lake sediments. Iournal of the North American Benthological Society 28:319-330.

Daraio, J. A., L. J. Weber, and T. J. Newton. 2010. Hydrodynamic modeling of juvenile mussel dispersal in a large river: the potential effects of bed shear stress and other parameters. lournal of the North American Benthological Society 29:838851. 
Defeo, O., and A. McLachlan. 2005. Patterns, processes and regulatory mechanisms in sandy beach macrofauna: a multi-scale analysis. Marine Ecology Progress Series 295:1-20.

Denny, M. 1988. Biology and the mechanics of the wave-swept environment. Princeton University Press, Princeton, New Jersey.

Dila, D. K., and B. A. Biddanda. 2015. From land to lake: contrasting microbial processes across a Great Lakes gradient of organic carbon and inorganic nutrient inventories. Journal of Great Lakes Research 41:75-85.

Doko, T., H. Fukui, A. Kooiman, A. G. Toxopeus, T. Ichinose, W. Chen, and A. K. Skidmore. 2011. Identifying habitat patches and potential ecological corridors for remnant Asiatic black bear (Ursus thibetanus japonicus) populations in Japan. Ecological Modelling 222:748-761.

EC and USEPA (Environment Canada and US Environmental Protection Agency). 2009. Nearshore areas of the Great Lakes 2009. EPA 905-R-09-013. US Environmental Protection Agency, Washington, DC. (Available from: https://binational.net//wp-con tent/uploads/2014/05/SOGL_2009_nearshore_en.pdf)

Elith, J., and C. H. Graham. 2009. Do they? How do they? WHY do they differ? On finding reasons for differing performances of species distribution models. Ecography 32:66-77.

Elith, J., C. H. Graham, R. P. Anderson, M. Dudik, S. Ferrier, A. Guisan, R. J. Hijmans, F. Huettmann, J. R. Leathwick, A. Lehmann, J. Li, L. G. Lohmann, B. A. Loiselle, G. Manion, C. Moritz, M. Nakamura, Y. Nakazawa, J. M. Overton, A. T. Peterson, S. J. Phillips, K. Richardson, R. Scachetti-Pereira, R. E. Schapire, J. Soberón, S. Williams, M. S. Wisz, and N. E. Zimmermann. 2006. Novel methods improve prediction of species' distributions from occurrence data. Ecography 29:129-151.

Gangloff, M. M., and J. W. Feminella. 2007. Stream channel geomorphology influences mussel abundance in southern Appalachian streams, USA. Freshwater Biology 52:64-74.

Graf, D. L. 2002. The historical biogeography and late glacial origin of the freshwater pearly mussel (Bivalvia:Unionidae) faunas of Lake Erie. Museum of Comparative Zoology, Occasional Papers on Mollusks 6:175-210.

Guisan, A., and W. Thuiller. 2005. Predicting species distribution: offering more than simple habitat models. Ecology Letters 8: 993-1009.

Guisan, A., R. Tingley, J. B. Baumgartner, I. Naujokaitis-Lewis, P. R. Sutcliffe, A. I. T. Tulloch, T. J. Regan, L. Brotons, E. McDonald-Madden, C. Mantyka-Pringle, T. G. Martin, J. R. Rhodes, R. Maggini, S. A. Setterfield, J. Elith, M. W. Schwartz, B. A. Wintle, O. Broennimann, M. Austin, S. Ferrier, M. R. Kearney, H. P. Possingham, and Y. M. Buckley. 2013. Predicting species distributions for conservation decisions. Ecologv Letters 16:1424-1435.

Haag, W. R. 2012. North American freshwater mussels: natural history, ecology, and conservation. Cambridge University Press, New York

Haag, W. R., and M. L. Warren. 1998. Role of ecological factors and reproductive strategies in structuring freshwater mussel communities. Canadian Journal of Fisheries and Aquatic Sciences 55:297-306.

Harris, A. T., D. A. Woolnough, and D. T. Zanatta. 2011. Insular lake island biogeography: using lake metrics to predict diversity in littoral zone mollusk communities. Lournal of the North American Benthological Society 30:997-1008.
Herborg, L. M., J. M. Drake, J. D. Rothlisberger, and J. M. Bossenbroek. 2009. Identifying suitable habitat for invasive species using ecological niche models and the policy implications of range forecasts. Pages 63-82 in R. P. Keller, D. M. Lodge, M. A. Lewis, and J. F. Shogren (editors). Bioeconomics of invasive species: integrating ecology, economics, policy, and management. Oxford University Press, New York.

Herdendorf, C. E. 1992. Lake Erie coastal wetlands: an overview. Iournal of Great Lakes Research 18:533-551.

Hill, N. M., P. A. Keddy, and I. C. Wisheu. 1998. A hydrological model for predicting the effects of dams on the shoreline vegetation of lakes and reservoirs. Environmental Management 22:723-736.

Hoffman, J. R., T. J. Morris, and D. T. Zanatta. 2018. Genetic evidence for canal-mediated dispersal of Mapleleaf, Quadrula quadrula (Bivalvia:Unionidae) on the Niagara Peninsula, Canada. Freshwater Science 37:82-95.

Hollandsworth, D., and R. Lowe. 2011. Indigenous unionid clam refugia from zebra mussels in Michigan inland lakes. American Midland Naturalist 166:369-378.

Inoue, K., K. Stoeckl, and J. Geist. 2017. Joint species models reveal the effects of environment on community assemblage of freshwater mussels and fishes in European rivers. Diversity and Distributions 23:284-296.

Jost, L. 2006. Entropy and diversity. Oikos 113:363-375.

Karatayev, A. Y., L. E. Burlakova, and D. K. Padilla. 1998. Physical factors that limit the distribution and abundance of Dreissena polymorpha (Pall.). Journal of Shellfish Research 17:12191235.

Kat, P. W. 1986. Hybridization in a unionid faunal suture zone. Malacologia 27:107-125.

Keddy, P. A., and A. A. Reznicek. 1986. Great Lakes vegetation dynamics - the role of fluctuating water levels and buried seeds. Journal of Great Lakes Research 12:25-36.

Krebs, R. A., E. M. Barkett, and M. T. Begley. 2015. The impact of dreissenid mussels on growth of the Fragile Papershell (Leptodea fragilis), the most abundant unionid species in Lake Erie. Canadian Journal of Zoology 93:143-148.

Krebs, R. A., W. C. Borden, E. R. Steiner, M. S. Lyons, W. Zawiski, and B. M. Walton. 2010. Determinants of mussel diversity in Lake Erie tributaries. Journal of the North American Benthological Society 29:506-520.

Lee, D. H., C. Morse, and S. Bandhu. 1998. Great Lakes and St. Lawrence River medium resolution vector shoreline data. Technical Memorandum ERL GLERL-104. National Great Lakes Environmental Research Laboratory, Oceanic and Atmospheric Administration, Ann Arbor, Michigan.

Lozier, J. D., and N. J. Mills. 2011. Predicting the potential invasive range of light brown apple moth (Epiphyas postvittana) using biologically informed and correlative species distribution models. Biological Invasions 13:2409-2421.

Lucy, F. E., L. E. Burlakova, A. Karatayev, S. Mastitsky, and D. Zanatta. 2014. Zebra mussel impacts on unionids: a synthesis of trends in North America and Europe. Pages 623-646 in D. W. Schloesser and T. F. Nalepa (editors). Quagga and zebra mussels: biology, impact, and control. $2^{\text {nd }}$ edition. CRC Press, Boca Raton, Florida.

Lydeard, C., R. H. Cowie, W. F. Ponder, A. E. Bogan, P. Bouchet, S. A. Clark, K. S. Cummings, T. J. Frest, O. Gargominy, D. G. 
Herbert, R. Hershler, K. E. Perez, B. Roth, M. Seddon, E. E. Strong, and F. G. Thompson. 2004. The global decline of nonmarine mollusks. BioScience 54:321-330.

Matawa, F., A. Murwira, and K. S. Schmidt. 2012. Explaining elephant (Loxodonta africana) and buffalo (Syncerus caffer) spatial distribution in the Zambezi Valley using maximum entropy modelling. Ecological Modelling 242:189-197.

McGoldrick, D. J., J. L. Metcalfe-Smith, M. T. Arts, D. W. Schloesser, T. J. Newton, G. L. Mackie, E. M. Monroe, J. Biberhofer, and K. Johnson. 2009. Characteristics of a refuge for native freshwater mussels (Bivalvia:Unionidae) in Lake St. Clair. Journal of Great Lakes Research 35:137-146.

McKenna, J. E., and C. Castiglione. 2010. Hierarchical multi-scale classification of nearshore aquatic habitats of the Great Lakes: Western Lake Erie. Journal of Great Lakes Research 36:757771.

Metcalfe-Smith, J. L., S. K. Staton, G. L. Mackie, and N. M. Lane. 1998. Changes in the biodiversity of freshwater mussels in the Canadian waters of the lower Great Lakes drainage basin over the past 140 years. Iournal of Great Lakes Research 24:845858.

Nelson, K. M., C. R. Ruetz, and D. G. Uzarski. 2009. Colonisation by Dreissena of Great Lakes coastal ecosystems: how suitable are wetlands? Freshwater Biology 54:2290-2299.

Newton, T. J., D. A. Woolnough, and D. L. Strayer. 2008. Using landscape ecology to understand and manage freshwater mussel populations. Journal of the North American Benthological Society 27:424-439.

Nichols, S. J., and D. A. Wilcox. 1997. Burrowing saves Lake Erie clams. Nature 389:921-921.

Phillips, S. J., R. P. Anderson, and R. E. Schapire. 2006. Maximum entropy modeling of species geographic distributions. Ecological Modelling 190:231-259.

Phillips, S. J., and M. Dudik. 2008. Modeling of species distributions with MaxEnt: new extensions and a comprehensive evaluation. Ecography 31:161-175.

Rashleigh, B. 2008. Nestedness in riverine mussel communities: patterns across sites and fish hosts. Ecography 31:612-619.

Razgour, O., J. Hanmer, and G. Jones. 2011. Using multi-scale modelling to predict habitat suitability for species of conservation concern: the grey long-eared bat as a case study. Biological Conservation 144:2922-2930.

Schloesser, D. W., R. Smithee, G. Longton, and W. Kovalak. 1997. Zebra mussel induced mortality of unionids in firm substrata of western Lake Erie and a habitat for survival. American Malacological Bulletin 14:67-74.
Schwalb, A. N., T. J. Morris, N. E. Mandrak, and K. Cottenie. 2013. Distribution of unionid freshwater mussels depends on the distribution of host fishes on a regional scale. Diversity and Distributions 19:446-454.

Sherman, J. J., B. A. Murry, D. A. Woolnough, D. T. Zanatta, and D. G. Uzarski. 2013. Assessment of remnant unionid assemblages in a selection of Great Lakes coastal wetlands. Journal of Great Lakes Research 39:201-210.

Strayer, D. 2008. Freshwater mussel ecology: a multifactor approach to distribution and abundance. University of California Press, Berkeley, California.

Strayer, D. L., and S. E. G. Findlay. 2010. Ecology of freshwater shore zones. Aquatic Sciences 72:127-163.

Strayer, D. L., and K. J. Jirka. 1997. The pearly mussels of New York State. New York State Museum Memoir 26. State Education Department, Albany, New York.

Strayer, D. L., and H. M. Malcom. 2007. Effects of zebra mussels (Dreissena polymorpha) on native bivalves: the beginning of the end or the end of the beginning? Journal of the North American Benthological Society 26:111-122.

Swets, J. A. 1988. Measuring the accuracy of diagnostic systems. Science 240:1285-1293.

van Buuren, S., and K. Groothuis-Oudshoorn. 2011. Mice: multivariate imputation by chained equations in R. Journal of Statistical Software 45:1-67.

Watters, G. T. 1992. Unionids, fishes, and the species-area curve. Journal of Biogeography 19:481-490.

Wenger, S. J., and J. D. Olden. 2012. Assessing transferability of ecological models: an underappreciated aspect of statistical validation. Methods in Ecology and Evolution 3:260-267.

Zanatta, D. T., J. M. Bossenbroek, L. E. Burlakova, T. D. Crail, F. de Szalay, T. A. Griffith, D. Kapusinski, A. Y. Karatayev, R. A. Krebs, E. S. Meyer, W. L. Paterson, T. J. Prescott, M. T. Rowe, D. W. Schloesser, and M. C. Walsh. 2015. Distribution of native mussel (Unionidae) assemblages in coastal areas of Lake Erie, Lake St. Clair, and connecting channels, twenty-five years after a dreissenid invasion. Northeastern Naturalist 22:223-235.

Zanatta, D. T., G. L. Mackie, J. L. Metcalfe-Smith, and D. A. Woolnough. 2002. A refuge for native freshwater mussels (Bivalvia:Unionidae) from impacts of the exotic zebra mussel (Dreissena polymorpha) in Lake St. Clair. Journal of Great Lakes Research 28:479-489.

Zigler, S. J., T. J. Newton, J. J. Steuer, M. R. Bartsch, and J. S. Sauer. 2008. Importance of physical and hydraulic characteristics to unionid mussels: a retrospective analysis in a reach of large river. Hydrobiologia 598:343-360. 